\title{
Pengaruh Model Pembelajaran Treffinger Berbantuan Alat Peraga Terhadap Pemahaman Konsep Matematis Peserta Didik
}

\author{
Nurhayati T. ${ }^{1}$, Jamal Fakhri ${ }^{2}$, Rizki Wahyu Yunian Putra ${ }^{3}$, Adolf Simatupang ${ }^{4}$ \\ Program Studi Pendidikan Matematika, Fakultas Tarbiyah dan Keguruan, Universitas Islam Negeri Raden Intan Lampung, \\ Jl. Letnal Kolonel H. J1 Endro Suratmin Sukarame, kec. Sukarame, Kota Bandar Lampung, Indonesia \\ nurhayati14tanjung@gmail.com
}

\begin{abstract}
Mathematical concept understanding is an ability that must be possessed by students to know mathematical material. This study aims to determine the effect of the treffinger learning model assisted by learning aids on students' mathematichal concept understanding. This research is quasi-experimental research and the method used is quantitative research. The population in this study were students of class XI at SMK Amal Bakti Jatimulyo. The sample in this study was divided into 3 classes, namely class XI Ak.1 and XI Ak.2 as the experimental class and class XI TKR as the control class. In this study, the instrument used was a test instrument in the form of questions. Analysis of the data used is hypothesis testing with Anova and multiple comparison tests. From the results of the calculation of data analysis shows that there is an influence of the Treffinger learning model on increasing the ability to understand mathematical concepts.
\end{abstract}

Keywords: Treffinger, Props, Understanding of Mathematical Concepts

\begin{abstract}
Abstrak
Pemahaman konsep matematis merupakan kemampuan yang harus dimiliki peserta didik untuk menguasai materi matematika. Penelitian ini bertujuan untuk mengetahui pengaruh model pembelajaran treffinger berbantuan alat peraga terhadap kemampuan pemahaman konsep matematis. Penelitian ini merupakan penelitian eksperimen semu dan metode yang digunakan adalah penelitian kuantitatif. Populasi pada penelitian ini adalah peserta didik kelas XI di SMK Amal Bakti Jatimulyo. Sampel dalam penelitian ini terbagi menjadi tiga kelas yaitu kelas XI Ak.1 dan XI Ak.2 sebagai kelas eksperimen dan kelas XI TKR sebagai kelas kontrol. Dalam penelitian ini instrumen yang digunakan adalah instrumen tes berupa soal. Analisis data yang digunakan adalah uji hipotesis dengan Anova dan uji komparasi ganda. Dari hasil perhitungan analisis data menunjukkan bahwa adanya pengaruh model pembelajaran treffinger terhadap peningkatan kemampuan pemahaman konsep matematis.
\end{abstract}

Kata kunci: Treffinger, Alat Peraga, Pemahaman Konsep Matematis

Copyright (c) 2021 Nurhayati T., Jamal Fakhri, Rizki Wahyu Yunian Putra

$\triangle$ Corresponding author: Nurhayati T.

Email Address: nurhayati14tanjung@gmail.com (Jalan Kopi 4 - Perumnas Way Halim, Bandar Lampung)

Received 29 June 2021, Accepted 15 July 2021, Published 02 August 2021

\section{PENDAHULUAN}

Perkembangan ilmu pengetahuan dan teknologi mempengaruhi perkembangan dalam dunia pendidikan. Seseorang akan memperoleh berbagai macam ilmu pengetahuan maupun ilmu teknologi melalui sebuah pendidikan. Pendidikan adalah usaha sadar dan terencana guna mewujudkan suasana belajar dan proses pembelajaran agar peserta didik secara aktif mengembangkan potensi dirinya untuk memiliki kekuatasn spiritual keagamaan, pengendalian diri, kepribadian, kecerdasan, akhlak memulai serta keterampilan yang diperlukan dirinya, masyarakat, bangsa serta negara(Waani \& Kandowangko, 2019). Oleh karena itu, melalui sebuah pendidikan baik pendidikan yang bersifat formal atau pendidikan non formal diharapkan seseorang akan mengalami suatu proses perubahan dari dalam dirinya seperti dalam pengetahuan maupun kelakuan (Rista \& Ariyanto, t.t.).

Perkembangan ilmu sains dan teknologi tidak lepas dari peranan matematika. Dan matematika menjadi dasar dari perkembangan suatu teknologi modern dan mempunyai peran untuk mengembangkan 
Pengaruh Model Pembelajaran Treffinger Berbantuan Alat Peraga Terhadap Pemahaman Konsep Matematis Peserta Didik, Nurhayati T., Jamal Fakhri, Rizki Wahyu Yunian Putra, Adolf Simatupang

daya pikir manusia (Darma \& Karma, 2020). Matematika merupakan ilmu pelajaran sebagai alat berkomunikasi, berpikir, alat sebagai pemecah persoalan praktis yang mempunyai unsur intuisi dan logika, konstruksi dan analisis, personalitas dan umum dan mempunyai bagian antara lain aljabar, aritmatika, analisis dan geometri (Subarianto dkk., 2019).

Memahami satu konsep di dalam matematika menjadi dasar untuk peserta didik menyenangi matematika (Muslina, 2017). Pemahaman konsep merupakan salah satu hal sulit didalam pelajaran matematika, oleh karena itu hanya sedikit dari beberapa peserta didik yang dapat memahami suatu konsep matematika dari materi yang pendidik sudah ajarkan ke peserta didik (Mukhayat dkk., 2020). Dilihat dari hasil survey yang dilakukan oleh Trends in Inter-national Mathematics and Science Study (TIMSS) tahun 2015 dikatakan bahwa Indonesia menempati peringkat ke 44 dari 49 negara dalam pembelajaran matematika. Dimana aspek yang dinilai dalam matematika adalah pengetahuan tentang fakta, prosedur, konsep, penerapan pengetahuan dan pemahaman konsep.

Tabel 1. Hasil TIMSS Indonesia (Hadi, 2019)

\begin{tabular}{|c|c|c|c|c|}
\hline \multicolumn{5}{|c|}{ Hasil TIMSS } \\
\hline Tahun & Peringkat & Peserta & $\begin{array}{c}\text { Rata-rata Skor } \\
\text { Indonesia }\end{array}$ & $\begin{array}{c}\text { Rata-rata Skor } \\
\text { Internasional }\end{array}$ \\
\hline 2003 & 35 & 46 Negara & 411 & 467 \\
\hline 2007 & 36 & 46 Negara & 397 & 500 \\
\hline 2011 & 38 & 42 Negara & 386 & 500 \\
\hline 2015 & 44 & 49 Negara & 397 & 500 \\
\hline
\end{tabular}

Berdasarkan tabel 1 menunjukan bahwa pada tahun 2015 Indonesia memperoleh pencapaian ratarata skor Indonesia yakni 397. Hasil tersebut juga mengakibatkan Indonesia masuk dalam kategori tingkat rendah serta berada di bawah skor rata-rata Internasional yaitu 500, dimana 400 ditetapkan sebagai bagian yang termasuk dibawah standar rendah. Salah satu aspek penilaian matematika oleh Trends in International Mathematics and Science (TIMSS) adalah pemahaman konsep, maka menunjukan bahwa kemampuan pemahaman konsep matematis peserta didik di Indonesia masih tergolong rendah.

Berdasarkan hasil wawancara dengan salah satu pendidik mata pelajaran matematika bahwa pembelajaran menggunakan model pembelajran konvensional (metode ceramah) membuat peserta didik kurang aktif dan jenuh setiap proses pembelajaran yang menyebabkan peserta didik sulit memahami materi yang diajarkan oleh gurunya. Jika peserta didik mendapatkan contoh konkrit yang diketahui maka peserta didik akan lebih mudah paham dengan materi pembelajaran (Kesumawati, 2012). Pemanfaatan atau pengguanaan media pembelajaran juga merupakan salah satu hal yang menyebabkan proses pembelajaran menarik dan aktif.

Keberhasilan dari suatu proses pembelajaran disebabkan karena beberapa faktor salah satunya pemilihan model atau metode pembelajaran yang sesuai. Jadi, pendidikan dikatakan berhasil apabila proses belajar-mengajarnya berjalan dengan baik serta menghasilkan output yang berkualitas (Maesaroh, 1970). Salah satu cara untuk permasalahan mengenai kurangnya minat peserta didik dengan mata pelajaran 
matematika yaitu dengan kemampuan pemahaman konsep pada peserta didik (Putro dkk., 2019). Pembelajaran yang tepat sangat dibutuhkan dalam mengakomodasi suatu peningkatan kompetensi peserta didik sehingga memperoleh hasil belajar yang lebih baik.

Alternatif model pembelajaran yang dapat digunakan untuk permasalahan yang telah diuraikan yaitu model pembelajaran treffinger. Model pembelajaran treffinger merupakan model yang melibatkan keterampilan kognitif dan afektif pada setiap proses pembelajarannya (Yulinsa dkk., 2021) yang dapat berpengaruh dalam proses pemahaman konsep matematis peserta didik. Proses pembelajaran yang peserta didiknya secara langsung berinteraksi dengan model matematika yang realistik, dan pembelajaran yang tidak membosankan yaitu proses pembelajaran yang memanfaatkan penggunaan alat peraga. Penggunaan media seperti alat peraga dapat mendorong keinginan dan minat baru, membangkitkan motivasi serta aktif dalam kegiatan pembelajaran(Wildaniati, 2019). Oleh karena itu, berdasarkan dari permasalahan yang sudah dijelaskan sebelumnya maka peneliti melakukan penelitian untuk mengetahui pengaruh penerapan model pembelajaran treffinger berbantuan alat peraga terhadap pemahaman konsep matematis peserta didik.

\section{METODE}

Pelaksanaan penelitian dilakukan di sekolah SMK Amal Bakti Jatimulyo. Penelitian yang dilakukan peneliti adalah penelitian kuantitatif. Penelitian ini termasuk kedalam jenis penelitian dengan metode Quasi Experiment Design dengan dua kelompok penelitian antara lain kelompok penelitian kelas eksperimen dan kelas kontrol (Putra, 2016). Populasi pada penelitian ini adalah seluruh peserta didik kelas XI di SMK Amal Bakti Jatimulyo. Sampel dipilih menggunakan teknik sampling sehingga terpilih kelas XI Ak.2 (kelas eksperimen 1) menggunakan model pembelajaran treffinger, XI Ak.1 (kelas eksperimen 2) menggunakan model pembelajaran treffinger berbantuan alat peraga dan XI TKR (kelas kontrol) dengan perlakuan model pembelajaran konvensional.

Variabel penelitian ini ada 2 yaitu variabel bebas dan variabel terikat. Variable bebas yaitu model pembelajaran treffinger berbantuan alat peraga sedangkan variabel terikat yaitu kemampuan pemahaman konsep matematis. Dalam penelitian ini menggunakan teknik pengumpulan data yang berupa tes dan wawancara. Tes yang dilakukan oleh peserta didik ialah tes soal materi Transformasi Geometri. Tes kemampuan dilakukan dua kali yaitu pretest yang merupakan test awal dilakukan untuk mengambil data tes kemampuan awal peserta didik sebelum adanya perlakuan model pembelejaran dan kemudian test akhir posttest kemampuan dilaksanakan setelah adanya perlakuan pada kelas eksperimen dan kelas kontrol. Setelah semua data tes kemampuan terkumpul dilakukan analisis data. Penguji cobaan instrumen soal yang peniliti dilakukan antara lain uji validitas, reliabilitas, tingkat kesukaran dan uji daya pembeda soal. Teknik analisis data yang digunakan peneliti ialah uji Anova satu jalan, dengan uji prasyarat menggunakan uji normalitas dan homogenitas. Untuk mengetahui besarnya peningkatan kemampuan pemahaman konsep dilihat dari uji N-Gain. 


\section{HASIL DAN DISKUSI}

\section{Hasil}

Penelitian dilakukan pada peserta didik kelas XI di SMK Amal Bakti Jatimulyo dengan sampel sebanyak tiga kelas yaitu kelas XI Ak.1, XI Ak.2 dan XI TKR yang setiap kelasnya kelas berisi 30 peserta didik. Materi yang diajarkan pada penelitian ini adalah materi Transformasi selama 4 kali pertemuan. Tes dalam pretest dan posttest yaitu terdapat 7 butir soal yang telah melalui uji coba instrumen.

Sebelum proses pembelajaran dilakukan disetiap kelas dengan menerapakan model pembelajaran yang telah ditentukan, peserta didik diberikan tes berupa soal (pretest) untuk melihat kemampuan awal pemahaman konsep peserta didik sebelum adanya perlakuan model pembelajaran. Kemudian setelah diberikan perlakuan model pembelajaran, peserta didik diberikan tes berupa soal (posttest) untuk melihat hasil akhir kemampuan pemahamn peserta didik setelah adanya perlakuan model pembelajaran yang diterapkan.

Penelitian pada kelas eksperimen menggunakan model pembelajran treffinger terdapat 3 tahapan pembelajaran yaitu : 1) Understanding challenge (memahami tantangan); 2) Generating ideas (membangkitkan gagasan); 3) Preparing for action (mempersiapkan tindakan).(Nurjannah \& Saputro, 2020). Yang membedakan kelas eksperimen 1 dan 2 yaitu pada kelas eksperimen 1 menerapkan model pembelajaran treffinger sedangkan pada kelas eksperimen 2 menerapkan model pembelajaran treffinger berbantuan alat peraga. Pada kelas eksperimen 2 pada tahap Generating Ideas (membangkitkan gagasan) kegiatan pembelajaran dalam penjelasan materi dan diskusi berbantuan alat peraga. Sedangkan pada kelas kontrol menerapkan model pembelajaran konvensioal dengan menggunakan metode ceramah.

Hasil data awal (pretest) dan data akhir (posttest) hasil penelitian tes kemampuan pemahaman konsep matematis pada kelas eksperimen dan kontrol dapat dilihat pada tabel 2 dan tabel 3 berikut ini.

Tabel 2. Deskripsi Data Awal (pretest) Kemampuan Pemahaman Konsep Matematis

\begin{tabular}{|l|c|c|c|c|c|c|c|}
\hline \multirow{2}{*}{ Kelompok } & \multirow{2}{*}{$\mathrm{X}_{\max }$} & \multirow{2}{*}{$\mathrm{X}_{\min }$} & \multicolumn{3}{|c|}{$\begin{array}{c}\text { Ukuran Tendensi } \\
\text { Sentral }\end{array}$} & \multicolumn{2}{c|}{$\begin{array}{c}\text { Ukuran } \\
\text { Variansi } \\
\text { Kelompok }\end{array}$} \\
\cline { 4 - 8 } & & & $\bar{x}$ & $\mathrm{M}_{\mathrm{o}}$ & $\mathrm{M}_{\mathrm{e}}$ & $\mathrm{R}$ & $\mathrm{Sd}$ \\
\hline Eks 1 & 43 & 18 & 27,77 & 18 & 29 & 25 & 7,73 \\
\hline Eks 2 & 46 & 14 & 28,10 & 29 & 29 & 32 & 8,16 \\
\hline Kontrol & 39 & 14 & 26,30 & 32 & 27 & 25 & 6,32 \\
\hline
\end{tabular}

Berdasarkan tabel 2 diatas rata-rata pretest pada eksperimen 1 adalah 27,77, pada kelas eksperimen 2 adalah 28,10 dan pada kelas kontrol adalah 26,30.

Tabel 3. Deskripsi Data Akhir (posttest) Kemampuan Pemahaman Konsep Matematis

\begin{tabular}{|c|c|c|c|c|c|c|c|}
\hline \multirow{2}{*}{ Kelompok } & \multirow{2}{*}{$\mathrm{X}_{\max }$} & \multirow{2}{*}{$\mathrm{X}_{\min }$} & \multicolumn{3}{|c|}{$\begin{array}{c}\text { Ukuran Tendensi } \\
\text { Sentral }\end{array}$} & \multicolumn{2}{c|}{$\begin{array}{c}\text { Ukuran } \\
\text { Variansi } \\
\text { Kelompok }\end{array}$} \\
\cline { 4 - 8 } & & & $\bar{x}$ & $\mathrm{M}_{\mathrm{o}}$ & $\mathrm{M}_{\mathrm{e}}$ & $\mathrm{R}$ & $\mathrm{Sd}$ \\
\hline Eksperimen 1 & 82 & 54 & 68,23 & 68 & 68 & 28 & 8,14 \\
\hline Eksperimen 2 & 82 & 54 & 69,87 & 68 & 69 & 28 & 8,37 \\
\hline
\end{tabular}




\begin{tabular}{|l|c|c|c|c|c|c|c|}
\hline Kontrol & 79 & 50 & 62,20 & 61 & 61 & 29 & 7,91 \\
\hline
\end{tabular}

Berdasarkan pada tabel 3 diatas menunjukkan bahwa rata-rata posttest pada kelas eksperimen 1adalah 68,23, pada kelas ekperimen 2 adalah 69,87 dan pada kelas ontrol adalah 62,20. Setelah hasil analisis data pretest dan posttest sudah diperoleh maka selanjutnya untuk melihat peningkatan kemampuan pemahaman konsep dilakukan uji N-Gain. Berikut ini data hasil uji normalitas N-Gain kemampuan pemahaman konsep matematis dengan uji Kolmogorov-Smirnov pada tabel 4.

Tabel 4. Uji Normalitas N-Gain Kemampuan pemahaman Konsep Matematis

\begin{tabular}{|c|c|c|c|c|c|c|}
\hline \multirow{2}{*}{ Kelas } & \multicolumn{3}{|c|}{ Kolmogorov-Smirnov ${ }^{\mathrm{a}}$} & \multicolumn{3}{c|}{ Shapiro-Wilk } \\
\cline { 2 - 7 } & Statistic & df & Sig. & Statistic & df & Sig. \\
\hline eks 1 &, 104 & 30 &, $200^{*}$ &, 969 & 30 &, 505 \\
\hline eks 2 &, 089 & 30 &, $200^{*}$ &, 967 & 30 &, 473 \\
\hline kontrol &, 094 & 30 &, $200^{*}$ &, 979 & 30 &, 805 \\
\hline
\end{tabular}

Dari tabel 4 terlihat nahwa pada masing-masing kelas memperoleh sig. 0,200 >0,05 maka $\mathrm{H}_{\mathrm{o}}$ diterima yang berarti ketiga kelas berdistribusi normal.

Tabel 5. Uji Homogenitas N-Gain Kemampuan Pemahaman Konsep Matematis

\begin{tabular}{|c|c|c|c|c|c|}
\hline \multicolumn{2}{|c|}{} & $\begin{array}{c}\text { Levene } \\
\text { Statistic }\end{array}$ & df1 & df2 & Sig. \\
\hline \multirow{4}{*}{ NGain } & Based on Mean &, 105 & 2 & 87 &, 900 \\
\cline { 2 - 6 } & Based on Median &, 107 & 2 & 87 &, 899 \\
\cline { 2 - 6 } & $\begin{array}{c}\text { Based on Median and with } \\
\text { adjusted df }\end{array}$ &, 107 & 2 & 0,86574 &, 899 \\
\cline { 2 - 6 } & Based on trimmed mean &, 107 & 2 & 87 &, 898 \\
\hline
\end{tabular}

Dari tabel 5 diperoleh nilai sign 0,900 >0,05 maka $\mathrm{H}_{\mathrm{o}}$ diterima yang berarti bahwa data kelas eksperimen dan kelas kontrol sebagai sampel kelas terpilih berasal dari populasi yang sama atau homogen. Jika data yang diperoleh sudah berdistribusi normal dan homogen maka selanjutnya dilakukan pengujian hipotesis menggunakan Uji ANOVA satu jalan, perhatikan tabel 6 berikut ini:

Tabel 6. Uji Anova

\begin{tabular}{|c|c|c|c|c|c|}
\hline & Sum of Squares & df & Mean Square & F & Sig. \\
\hline Between Groups &, 150 & 2 &, 075 & 7,874 &, 001 \\
\hline Within Groups &, 831 & 87 &, 010 & & \\
\hline Total &, 981 & 89 & & & \\
\hline
\end{tabular}

Pada tabel 6 diatas terlihat bahwa sig $<\propto$ yang dimana nilai $\propto=0,05$ dan sig pada tabel diatas adalah 0,001 maka dapat disimpulkan bahwa $\mathrm{H}_{0}$ ditolak yang berarti terdapat minimal satu pasang model yang memberikan rataan hasil yang berbeda. Selanjutnya melakukan uji lanjut atau uji komparasi ganda dengan metode Scheffe' menggunakan SPSS yang menghasilkan multiple comparisons yang disajikan pada tabel 7 berikut ini: 
Tabel 7. Uji Komparasi Ganda

\begin{tabular}{|c|c|c|c|c|c|c|}
\hline \multirow{2}{*}{ (I) Kelas } & $\begin{array}{c}\text { (J) } \\
\text { Kelas }\end{array}$ & $\begin{array}{c}\text { Mean } \\
\text { Difference (I- }\end{array}$ & $\begin{array}{c}\text { Std. } \\
\text { J) }\end{array}$ & Error & Sig. & \multicolumn{2}{|c|}{\begin{tabular}{c} 
In\% Confidence \\
\cline { 3 - 7 }
\end{tabular}} & & $\begin{array}{c}\text { Lower } \\
\text { Bound }\end{array}$ & $\begin{array}{c}\text { Upper } \\
\text { Bound }\end{array}$ \\
\hline \multirow{2}{*}{ Eks 1 } & eks 2 &,- 02116 &, 02523 &, 705 &,- 0840 &, 0417 \\
\cline { 2 - 7 } & kontrol &, $07419^{*}$ &, 02523 &, 016 &, 0113 &, 1370 \\
\hline \multirow{2}{*}{ eks 2 } & eks 1 &, 02116 &, 02523 &, 705 &,- 0417 &, 0840 \\
\cline { 2 - 7 } & kontrol &, $09534^{*}$ &, 02523 &, 001 &, 0325 &, 1582 \\
\hline \multirow{2}{*}{ kontrol } & eks1 &,$- 07419^{*}$ &, 02523 &, 016 &,- 1370 &,- 0113 \\
\cline { 2 - 7 } & eks 2 &,$- 09534^{*}$ &, 02523 &, 001 &,- 1582 &,- 0325 \\
\hline
\end{tabular}

Berdasarkan tabel 7 analisis komparasi ganda menunjukkan pada hipotesis pertama, $H_{o}: \mu_{1}=\mu_{2}$ $\mathrm{H}_{\mathrm{o}}$ diterima karena $p$-value $>0,05$. Pada hipotesis kedua $H_{o}: \mu_{1} \neq \mu_{3} \mathrm{H}_{\mathrm{o}}$ ditolak $p$-value $<0,05$. Pada hipotesis ketiga $H_{o}: \mu_{2} \neq \mu_{3} \mathrm{H}_{\mathrm{o}}$ ditolak. $p$-value $<0,05$.

\section{Diskusi}

Berdasarkan hasil analisis data dan uji komparasi ganda terdapat tiga hipotesis yaitu:

1. $H_{o}: \mu_{1}=\mu_{2} \mathrm{H}_{\mathrm{o}}$ diterima, karena nilai sig sebesar 0,494 $>\alpha$ berarti bahwa tidak adaperbedaan yang signifikan antara peserta didik dengan perlakuan model pembelajaran Treffinger dan peserta didik dengan perlakuan model pemebelajaran Treffinger berbantuan alat peraga terhadap kemampuan pemahaman konsep matematis peserta didik diantara kedua kelas tersebut. Maka dapat disimpulkan bahwa model pembelajaran Treffinger dan model pembelajaran Treffinger berbantuan alat peraga sama baiknya terhadap peningkatan kemampuan pemahaman konsep pserta didik.

2. $H_{o}: \mu_{1} \neq \mu_{3} \mathrm{H}_{\mathrm{o}}$ ditolak, karena diperoleh nilai sig sebesar 0,016> $\alpha$ yang berarti bahwa adanya perbedaan yang signifikan antara peserta didik di kelas eksperimen 1 dengan perlakuan model pembelajaran Treffinger dan peserta didik dikelas kontrol dengan perlakuan model konvensional menggunakan metode ceramah terhadap kemampuan pemahaman konsep matematis peserta didik. Sehingga dapat disimpulkan bahwa model pembelajaran Treffinger lebih baik daripada model pembelajaran konvensiona

3. $H_{o}: \mu_{2} \neq \mu_{3} \mathrm{H}_{\mathrm{o}}$ ditolak, karena diperoleh nilai sig sebesar $0,001>\alpha$ yang berarti bahwa adanya perbedaan yang signifikan antara peserta didik di kelas eksperimen 2 dengan perlakuan model pembelajaran Treffinger berbantuan alat peraga dan peserta didik dikelas kontrol dengan perlakuan model konvensional menggunakan metode ceramah terhadap kemampuan pemahaman konsep matematis peserta didik. Sehingga dapat disimpulkan bahwa model pembelajaran Treffinger berbantuan alat peraga lebih baik daripada model pembelajaran konvensional.

Dari hasil analisis data diatas diperoleh bahwa pada kelas kontrol (model pembelajaran konvensional) tidak terdapat pengaruh signifikan terhadap peningkatan kemampuan pemahaan konsep matematis dibandingkan dengan pada kedua kelas eksperimen. Pada kedua kelas eksperimen (model 
pembelajaran treffingerdan model pembelajarajn trefffinger berbantuan alat peraga) terdapat pengaruh peningkatan kemampuan pemahaman konsep matematis peserta didik.

Model pembelajaran treffinger dalam proses pembelajarannya membutuhkan waktu yang lama, akan tetapi dikarenakan waktu yang dipersingkat karena penelitian ini dilakukan pada saat masih dalam kondisi pandemi covid-19 menyebabkan kurang maksimalnya proses pembelajaran dari setiap tahapan model pembelajaran ini. Dalam proses pembelajaran ada beberapa faktor yang mempengaruhi pemahaman konsep peserta didik , salah satunya yaitu faktor dari lingkungan kelasnya dan motivasi dirinya(Puspa dkk., 2021). Pada kelas eksperimen peserta didik lebih terlihat aktif, nyaman dan juga antusias dalam kegiatan pembelajaran karena dalam penelitian iini metode pembelajaran yang digunakan ialah berkelompok heterogen. Menyebabkan peserta didik yang pemahaman konsep matematisnya rendah menjadi termotivasi dan juga terdorong oleh peserta didik yang memilki kemampuan pemahaman konsepnya tinggi. Dan juga karena proses dan kegiatan pembelajaran yang dilakukan dalam penelitian di kelas eksperimen 2 berbantuan alat peraga membuat peserta didik lebih tertarik mengikuti kegiatan pembelajaran.

Peserta didik pada kelas eksperimen sedikit sulit memahami pembelajaran pada setiap kegiatan pembelajaran yang dilakukan dan kurang maksimal untuk berdisukusi dan mempresentasikan dikarenakan harus mengimbangi dengan waktu yang dipersingkat selama proses pembelajaran tatap muka pada saat pandemi. Peserta didik pada kelas kontrol yang menggunakan metode ceramah selama pembelajaran terlihat sangat pasif dikarenakn proses pembelajaran hanya terfokus pada guru yang menjelaskan materi pembelajaran.

\section{KESIMPULAN}

Berdasarkan hasil penelitian dan analisis data yang sudah dijabarkan maka disimpulkan bahwa adanya peningkatan pemahaman konsep matematis peserta didik melalui model pembelajaran treffinger. Pada hasil uji lanjutan $N$-Gain terdapat perbedaan peningkatan kemampuan pemahaman konsep matematis peserta didik yang menunjukkan bahwa peningkatan kemampuan pemahaman konsep matematis pada model pembelajaran Treffinger berbantuan alat peraga lebih baik daripada model pembelajaran konvensional, akan tetapi sama baiknya dengan model pembelajaran Treffinger.

\section{UCAPAN TERIMA KASIH}

Ucapan syukur peneliti panjatkan kepada Allah SWT. karena telah memberi kelancaran serta kesabaran dalam proses penyelesaian artikel ini. Peneliti mengucapkan terima kasih juga pada keluarga terkhusus orang tua serta adik-adik yang selalu mendo'akan dan selalu mendukung penuh peniliti. Terima kasih peneliti ucapkan kepada seluruh pihak di sekolah SMK Amal Bakti Jatimulyo telah berkenan memberikan izin untuk melakukan penelitian.

\section{REFERENSI}

Darma, I. K., \& Karma, I. G. M. (2020). Blended Learning, Inovasi Strategi Pembelajaran Matematika Di Era Revolusi Industri 4.0 Bagi Pendidikan Tinggi. 3, 13. 
Hadi, S. (2019). (Trends In International Mathematics And Science Study). 8.

Kesumawati, N. (2012). Meningkatkan Kemampuan Pemahaman Matematis Siswa Smp Melalui Pendekatan Pendidikan Matematika Realistik Indonesia (Pmri). Jurnal Pendidikan Matematika, 6(2), $30-44$.

Maesaroh, S. (1970). Peranan Metode Pembelajaran Terhadap Minat Dan Prestasi Belajar Pendidikan Agama Islam. Jurnal Kependidikan, 1(1), 150-168. Https://Doi.Org/10.24090/Jk.V1i1.536

Mukhayat, A., Mujib, M., Putra, R. W. Y., Mardiyah, M., \& Simatupang, A. (2020). Meningkatkan Pemahaman Konsep Matematis Melalui Penerapan Model Pembelajaran Advance Organizer Berbantuan Media Adobe Flash. Journal Of Mathematics Education And Science, 3(1), 39-44.

Muslina, M. (2017). Upaya Meningkatkan Pemahaman Konsep Matematis Siswa Kelas 2 Sdn 133 Pekanbaru Melalui Penerapan Model Pembelajaran Langsung (Direct Learning). Jurnal Cendekia : Jurnal Pendidikan Matematika, 1(2), 92-99. Https://Doi.Org/10.31004/Cendekia.V1i2.60

Nurjannah, H., \& Saputro, A. (2020). The Application Of The Treffinger Learning Model In Learning Geography. 19(1), 15.

Puspa, S. D., Riyono, J., \& Puspitasari, F. (2021). Analisis Faktor-Faktor Yang Mempengaruhi Pemahaman Konsep Matematis Mahasiswa Dalam Pembelajaran Jarak Jauh Pada Masa Pandemi Covid-19. Jurnal Cendekia: Jurnal Pendidikan Matematika, 5(1), 302-320. Https://Doi.Org/10.31004/Cendekia.V5i1.533

Putra, R. W. Y. (2016). Pembelajaran Matematika Dengan Metode Accelerated Learning Untuk Meningkatkan Kemampuan Penalaran Adaptif. Al-Jabar: Jurnal Pendidikan Matematika, 7(2), 211220.

Putro, S. S. N., Soenarto, M., \& Faradillah, A. (2019). Pengaruh Model Discovery Learning Berbantu Software Wingeom Terhadap Kemampuan Pemahaman Konsep Matematis Peserta Didik. Majamath: $\begin{array}{lllll}\text { Jurnal Matematika Dan Pendidikan } & \text { Matematika, } & \text { 2(1), }\end{array}$ Https://Doi.Org/10.36815/Majamath.V2i1.240

Rista, K., \& Ariyanto, E. A. (T.T.). Pentingnya Pendidikan \& Meningkatkan Motivasi Belajar Anak. 2.

Subarianto, S., Ikhsan, M., \& Munzir, S. (2019). Meningkatkan Kemampuan Representasi Dan Pemecahan Masalah Matematis Siswa Melalui Pendekatan Problem Posing Dalam Pembelajaran Matematika. Jurnal Peluang, 7(1), 127-135.

Waani, F. J., \& Kandowangko, N. (2019). Peran Pendidikan Dalam Proses Perubahan Sosial Di Desa Tumaluntung Kecamatan Kauditan Kabupaten Minahasa Utara. 12(4), 18.

Wildaniati, Y. (2019). Penggunaan Alat Peraga Untuk Meningkatkan Hasil Belajar Siswa Kelas V Sd N 2 Gunung Katun Kecamatan Baradatu. Jurnal Dewantara, 7(01), 56-72.

Yulinsa, H., Putra, R. W. Y., \& Farida, F. (2021). Peningkatan Pemahaman Konsep Matematis Melalui Penerapan Model Pembelajaran Treffinger Berbantu Bahan Ajar Alqurun (Improving The Understanding Of Mathematic Concepts Through The Application Of Treffinger Learning Model Assisted With Alqurun Teaching Materials). Jurnal Ilmiah Didaktika: Media Ilmiah Pendidikan Dan Pengajaran, 21(2), 177. Https://Doi.Org/10.22373/Jid.V21i2.6640. 